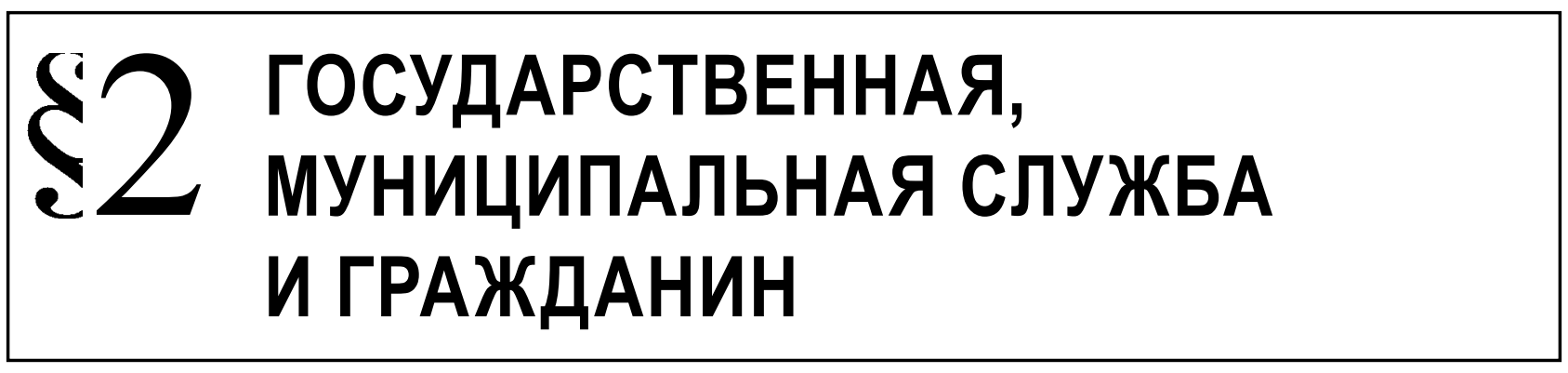

Полевец И.М.

\title{
ОСОБЕННОСТИ ВОЕННОЙ СЛУЖБЫ
}

\begin{abstract}
Аннотация: Предметом исследования являются особенности военной службы в Российской Федерации, совокупность признаков, характерных для военной службы, как вида федеральной государственной службы.Целью работы являются:рассмотреть признаки, характерные для военной службы, благодаря которым военную службу можно отличить от иных видов государственной службы;дать краткую характеристику данным признакам, с учетом норм действующего законодательства;установить основные отличия военной службы от гражданской государственной службы, а также особый вид военной службы. Сравнительный анализ норм действующего законодательства о военной службе, способствующий выявлению признаков характерных для военной службы, подчеркивающих особый статус военной службы. В результате исследования установлено, что большинство из перечисленных отличительных признаков военной службы имеют особый характер.Основные отличия военной службы от гражданской государственной службы заключается в предназначении этих видов государственной службы, в выполняемых ими функциях и задачах. Особенность военной службы заключается в исполнении военнослужащими специфических функций, в целях обеспечения обороны и безопасности Российской Федерации, специальными методами с применением или возможностью применения средств вооруженной борьбы (вооружения и военной техники) с противником, закрепленных федеральным законодательством.Специфика военной службы проявляется в том, что с учетом детальной регламентации правовыми актами военно-служебных отношений, не всегда представляется возможным, установить (определить) порядок действий военнослужащего в той или иной ситуации, в частности во время ведения боевых действий, что также подчеркивает особый статус военной службы.
\end{abstract}

Ключевые слова: особенности, военная служба, признаки, особый вид, ответственность, выплаты, довольствие, специфика, условия службы, безопасность.

$\mathrm{B}$ оенная служба характеризуется рядом признаков, благодаря которым ее можно отличить от иных видов государственной службы, хотя отдельные из них присущи и иным видам государственной службы, в частности правоохранительной.

Совпадение отдельных признаков обусловлено едиными принципами построения и функционирования системы государственной службы в Российской Федерации.

Таким образом, отличительные признаки обуславливают особый вид военной службы и, по мнению А.В. Кудашкина, выделяют ее из других видов государственной службы ${ }^{1}$. К этим

1 Кудашкин А.В. Статья: К вопросу о сущности военной службы и ее месте в системе государственной службы. «Пра- признакам можно отнести: 1) ее предназначенность, т.е. возможность применения специальных (военных) методов для решения поставленных задач, использование для этого средств вооруженной борьбы (оружия и вооружения как индивидуального, так и коллективного применения). Такая возможность не предоставляется любым другим видам государственной службы; 2) исполнение военной службы не только в добровольном порядке, но и по призыву как форме воинской обязанности, являющейся юридической обязанностью части населения государства, что также не присуще другим видам государственной службы.

во в Вооруженных Силах», № 8, 2003. 
На мой взгляд, рассматриваемому виду государственной службы присущ и ряд других признаков ${ }^{2}$ :

Специфика выполняемых задач и функций в области обороны и военной безопасности. В соответствии пунктом 1 статьи 10 Федерального закона от 31 мая 1996 г. № 61-Ф3 «Об обороне» (далее Закон об обороне) Вооруженные Силы Российской Федерации - государственная военная организация, составляющая основу обороны Российской Федерации ${ }^{3}$. Вооруженные Силы Российской Федерации предназначены для отражения агрессии, направленной против Российской Федерации, для вооруженной защиты целостности и неприкосновенности территории Российской Федерации, а также для выполнения задач в соответствии с федеральными конституционными законами, федеральными законами и международными договорами Российской Федерации (пункт 2 статьи 10 Закона об обороне).

В целях защиты интересов Российской Федерации и ее граждан, поддержания международного мира и безопасности формирования Вооруженных Сил Российской Федерации могут оперативно использоваться за пределами территории Российской Федерации в соответствии с общепризнанными принципами и нормами международного права, международными договорами Российской Федерации для решения следующих задач: отражение вооруженного нападения на формирования Вооруженных Сил Российской Федерации, другие войска или органы, дислоцированные за пределами территории Российской Федерации; отражение или предотвращение вооруженного нападения на другое государство, обратившееся к Российской Федерации с соответствующей просьбой; защита граждан Российской Федерации за пределами территории Российской Федерации от вооруженного нападения на них; борьба с пиратством и обеспечение безопасности судоходства.

Кроме того, к выполнению задач в области обороны привлекаются и другие войска, воинские формирования и органы.

Как видно на примере Вооруженных Сил Российской Федерации при прохождении военной службы военнослужащими исполняются специфические обязанности, в том числе участие в боевых

2 Корякин В.М., Кудашкин А.В., Фатеев К.В. Военно-административное право (военная администрация). Учебник. М.: За права военнослужащих, 2008. Вып. 90.496 с.

3 СЗ РФ, 03.06.1996, № 23, ст. 2750. действиях, которые связаны с риском для жизни и здоровья военнослужащего.

2) Наличие специальных принципов в организации военной службы. К данным принципам следует отнести: верность Российской Федерации; единоначалие и субординация на военной службе; соблюдение воинской дисциплины; непрерывность военной службы и постоянная готовность к защите Российской Федерации; обязательный профессиональный отбор при равном доступе к военной службе и равные условия ее; взаимосвязь прав, свобод, запретов, ограничений, обязанностей, ответственности и государственных гарантий военнослужащих; государственная защита военнослужащих, граждан, уволенных с военной службы, и членов их семей; принцип соразмерности и ответственности за принимаемые решения.

3) Особые условия службы, нередко сопряженные с риском для жизни и здоровья. Пунктом 2 статьи 1 Федерального закона от 27 мая 1998 г. № 76-Ф3 «0 статусе военнослужащих» (далее - Закон о статусе военнослужащих) установлено, что на военнослужащих возлагаются обязанности по подготовке к вооруженной защите и вооруженная защита Российской Федерации, которые связаны с необходимостью беспрекословного выполнения поставленных задач в любых условиях, в том числе с риском для жизни. В постановлении Пленума Верховного Суда Российской Федерации от 29 мая 2014 г. № 8 «0 практике применения судами законодательства о воинской обязанности, военной службе и статусе военнослужащих» указывается, что судам следует исходить из того, что предъявление к военнослужащим специальных требований, обусловленных особенностями военной службы, в том числе неукоснительное соблюдение воинской дисциплины, необходимость некоторых ограничений их прав и свобод, установленных федеральными законами, не может рассматриваться как нарушение прав военнослужащих свободно распоряжаться своими способностями к труду, выбирать род деятельности и профессию ${ }^{4}$.

В связи с особым характером обязанностей, возложенных на военнослужащих, им предоставляются социальные гарантии и компенсации : особые служебные обязанности (обязанности военной службы).

Статьи 26 и 27 Закона о статусе военнослужащих, а также Устав внутренней службы Воору-

\footnotetext{
4 РГ, № 124, 04.06.2014.

СЗ РФ, № 22, 01.06.1998, ст. 2331.
} 
женных Сил Российской Федерации (далее - Устав внутренней службы), утвержденный Указом Президента Российской Федерации от 10 ноября 2007 г. № 1495 «Об утверждении общевоинских уставов Вооруженных Сил Российской Федерации» предусматривают общие, должностные и специальные обязанности военнослужащего ${ }^{6}$.

К общим обязанностям военнослужащего относится: быть верными Военной присяге (обязательству), беззаветно служить народу Российской Федерации, мужественно и умело защищать Российскую Федерацию; строго соблюдать Конституцию Российской Федерации и законы Российской Федерации, требования общевоинских уставов, беспрекословно выполнять приказы командиров; дорожить воинской честью, боевой славой и войсковым товариществом; совершенствовать воинское мастерство, содержать в постоянной готовности к применению вооружение и военную технику, беречь военное имущество; быть дисциплинированными, бдительными, хранить государственную и военную тайну; соблюдать общепризнанные принципы и нормы международного права и международные договоры Российской Федерации.

Должностные обязанности военнослужащих устанавливаются применительно к занимаемой военнослужащим должности, которые определяют его полномочия, а также объем выполняемых им в соответствии с занимаемой воинской должностью задач.

Военнослужащие, находящиеся на боевом дежурстве (боевой службе), в суточном и гарнизонном нарядах, привлеченные для ликвидации последствий стихийных бедствий, а также при других чрезвычайных обстоятельствах, исполняют специальные обязанности.

Должностные обязанности, специальные обязанности и порядок их исполнения устанавливаются федеральными законами, общевоинскими уставами и иными нормативными правовыми актами Российской Федерации.

4) Регулирование военно-служебных отношений общевоинскими уставами Вооруженных Сил Российской Федерации. Устав внутренней службы определяет, что единоначалие является одним из основных принципов строительства Вооруженных Сил, руководства ими и взаимоотношений между военнослужащими. Единоначалие заключается в наделении командира (начальника) всей полнотой распорядительной власти по отношению к

6 СЗ РФ, № 47 (1 ч.), 19.11.2007, ст. 5749. подчиненным и возложении на него персональной ответственности перед государством за все стороны жизни и деятельности воинской части, подразделения и каждого военнослужащего.

Единоначалие выражается в праве командира (начальника), исходя из всесторонней оценки обстановки, единолично принимать решения, отдавать в установленном порядке соответствующие приказы и обеспечивать их выполнение.

По своему служебному положению и воинскому званию одни военнослужащие по отношению к другим могут быть начальниками или подчиненными.

Начальник имеет право отдавать подчиненному приказы и требовать их исполнения. Он должен быть для подчиненного примером тактичности, выдержанности и не должен допускать фамильярности и предвзятости по отношению к нему. Подчиненный обязан беспрекословно выполнять приказы начальника.

Военнослужащие, которые по своему служебному положению и воинскому званию не являются по отношению к другим военнослужащим их начальниками или подчиненными, могут быть старшими или младшими. Старшинство определяется воинскими званиями военнослужащих.

При совместном исполнении обязанностей военнослужащими, не подчиненными друг другу, когда их служебные взаимоотношения не определены командиром (начальником), старший из них по воинской должности, а при равных должностях старший по воинскому званию является начальником.

Наличие у военнослужащих воинских званий обеспечивает ясность и четкость во взаимоотношениях и субординации военнослужащих. Кроме того, воинское звание отражает служебный стаж и служебное положение военнослужащего. Для прохождения военной службы в каждом воинском звании устанавливается определенный срок.

При прохождении военной службы предусмотрены отношения подчиненности как по должности, так и по воинскому званию, что существенно отличает воинские звания от специальных званий других государственных служащих. Наличие воинских званий с их важным служебно-правовым значением также составляет одну из особенностей военной службы ${ }^{7}$.

5) Особые условия и порядок поступления на военную службу, ее прохождения, присвоения во-

Колибаба Г.Н. Правовые основы советской военной службы: Дис. канд. юрид. наук. М., 1955. С. 54. 
инских званий, назначения на должности, возложения временного исполнения обязанностей по воинской должности, зачисления в распоряжение командира (начальника), освобождения от воинских должностей, увольнения с военной службы. Данные вопросы регулируются Федеральным законом от 28 марта 1998 г. № 53-ФЗ «0 воинской обязанности и военной службе» ${ }^{8}$ и Указом Президента Российской Федерации от 16 сентября 1999г. № 1237 «Вопросы прохождения военной службы» ${ }^{9}$ В соответствии с этими актами гражданин, поступающий или призываемый на военную службу, должен соответствовать медицинским требованиям, а поступающий на военную службу по контракту, кроме того, и профессиональнопсихологическим требованиям, а также требованиям по уровню образования, профессиональной и физической подготовки.

Военнослужащий, впервые поступивший на военную службу, или гражданин, не проходивший военной службы и впервые призванный на военные сборы, приводится к Военной присяге перед Государственным флагом Российской Федерации и Боевым Знаменем воинской части.

Военнослужащий, являющийся иностранным гражданином, впервые поступивший на военную службу в Российской Федерации, дает обязательство.

До приведения к Военной присяге военнослужащий не может привлекаться к выполнению боевых задач (участию в боевых действиях, несению боевого дежурства, боевой службы, караульной службы) и задач при введении режима чрезвычайного положения и в условиях вооруженных конфликтов; за военнослужащим не могут закрепляться оружие и военная техника; на военнослужащего не может налагаться дисциплинарное взыскание в виде ареста.

После поступления (призыва) на военную службу, в пределах установленных сроков, военнослужащий не вправе по собственному желанию менять место службы, прекращать выполнение служебных обязанностей, самовольно покидать место прохождения военной службы.

Особенностью военной службы является то, что днем окончания (последним днем) военной службы, является не дата издания приказа об увольнении с военной службы, а дата исключения

\footnotetext{
С3 РФ, 30.03.1998, № 13, ст. 1475.

9 СЗ РФ, 20.09.1999, № 38, ст. 4534.
}

военнослужащего из списков личного состава воинской части.

наличие особого статуса военнослужащих;

Статус военнослужащих есть совокупность прав, свобод, гарантированных государством, а также обязанностей и ответственности военнослужащих, установленных Законом о статусе военнослужащих, федеральными конституционными законами, федеральными законами и иными нормативными правовыми актами Российской Федерации.

Военнослужащие обладают правами и свободами человека и гражданина с некоторыми ограничениями, установленными настоящим Федеральным законом, федеральными конституционными законами и федеральными законами.

Правовые нормы, регулирующие военнослужебные отношения, являются специальными правовыми нормами. Их действие распространяется на определенный круг лиц, несущих военную службу. Действие данных норм не распространяется на граждан, проходящих альтернативную службу, призывников, лиц, находящихся в запасе, если они в данное время не проходят военные сборы ${ }^{10}$.

6) Особый порядок привлечения к юридической ответственности. Статья 28 Закона о статусе военнослужащих и статьи 26-32 Устава внутренней службы устанавливают, что военнослужащий или гражданин, призванный на военные сборы, в зависимости от характера и тяжести совершенного им правонарушения привлекается к дисциплинарной, административной, материальной, гражданско-правовой и уголовной ответственности в соответствии с настоящим Федеральным законом и другими федеральными законами.

К дисциплинарной ответственности военнослужащие привлекаются за дисциплинарные проступки, то есть за противоправные, виновные действия (бездействие), выражающиеся в нарушении воинской дисциплины, которые в соответствии с законодательством Российской Федерации не влекут за собой уголовной или административной ответственности.

За административные правонарушения военнослужащие несут дисциплинарную ответственность в соответствии с Дисциплинарным уставом Вооруженных Сил Российской Федерации, за исключением административных правонарушений,

10 Попов Л.Л., Мигачев Ю.И., Тихомиров С.В. Административное право России: учебник. - 2-е изд., перераб. и доп. (отв. ред. Попов Л.Л.). - М.: Проспект, 2010. 
за которые они несут ответственность на общих основаниях.

При этом к военнослужащим не могут быть применены административные наказания в виде административного ареста, обязательных работ, а к сержантам, старшинам, солдатам и матросам, проходящим военную службу по призыву, курсантам военных профессиональных образовательных организаций, военных образовательных организаций высшего образования до заключения с ними контракта о прохождении военной службы - в виде административного штрафа.

К материальной ответственности военнослужащие привлекаются за материальный ущерб, причиненный по их вине государству при исполнении обязанностей военной службы, в соответствии с законодательством Российской Федерации.

К гражданско-правовой ответственности военнослужащие привлекаются за невыполнение или ненадлежащее исполнение предусмотренных федеральными законами и иными нормативными правовыми актами Российской Федерации обязательств, за убытки и моральный вред, причиненные военнослужащими, не находящимися при исполнении обязанностей военной службы, государству, физическим и юридическим лицам, и в других случаях, предусмотренных федеральными законами и иными нормативными правовыми актами Российской Федерации.

К уголовной ответственности военнослужащие привлекаются за совершение преступления, предусмотренного уголовным законодательством Российской Федерации.

В случае совершения правонарушения, связанного с причинением государству материального ущерба, военнослужащие возмещают ущерб независимо от привлечения к дисциплинарной, административной или уголовной ответственности за действия (бездействие), которыми причинен ущерб.

7) Специальное обеспечение (денежное довольствие, социальные гарантии, форма). Статья 12 Закона о статусе военнослужащих предусматривает, что военнослужащие обеспечиваются денежным довольствием в порядке и в размерах, установленных Федеральным законом «О денежном довольствии военнослужащих и предоставлении им отдельных выплат», иными федеральными законами, указами Президента Российской Федерации, постановлениями Правительства Российской Федерации, нормативными правовыми актами федеральных органов исполнительной власти и иных федеральных государственных органов.
Федеральный закон от 7 ноября 2011 г. № 306Ф3 «0 денежном довольствии военнослужащих и предоставлении им отдельных выплат» устанавливает, что денежное довольствие военнослужащих, проходящих военную службу по контракту, является основным средством их материального обеспечения и стимулирования исполнения обязанностей военной службы ${ }^{11}$. Денежное довольствие военнослужащего, проходящего военную службу по контракту, состоит из месячного оклада в соответствии с присвоенным воинским званием и месячного оклада в соответствии с занимаемой воинской должностью, которые составляют оклад месячного денежного содержания военнослужащего и из ежемесячных и иных дополнительных выплат.

Денежное довольствие военнослужащего, проходящего военную службу по призыву, состоит из оклада по воинской должности и дополнительных выплат.

Размеры окладов по типовым воинским должностям в Вооруженных Силах Российской Федерации, других войсках и воинских формированиях, в Службе внешней разведки Российской Федерации, Федеральной службе безопасности Российской Федерации, Федеральной службе охраны Российской Федерации и Службе специальных объектов при Президенте Российской Федерации, подлежащим замещению военнослужащими, проходящими военную службу по контракту, а также размеры окладов по воинским званиям военнослужащих, проходящих военную службу по контракту, установлены постановлением Правительства Российской Федерации от 5 декабря 2011 г. № 992 «Об установлении окладов денежного содержания военнослужащих, проходящих военную службу по контракту» ${ }^{12}$.

Размеры окладов по типовым воинским должностям и размеры дополнительных выплат военнослужащим, проходящих военную службу по призыву, установлены постановлением Правительства Российской Федерации от 21 декабря 2011 г. № 1072 «0 денежном довольствии военнослужащих, проходящих военную службу по призыву ${ }^{13}$. Военнослужащему, проходящему военную службу по призыву, устанавливаются следующие дополнительные выплаты: ежемесячная надбавка за классную квалификацию (квалификационную категорию, квалифи-

\footnotetext{
11 С3 РФ, 07.11.2011, № 45, ст. 6336.

12 РГ, № 278, 09.12.2011.

13 РГ, № 293, 28.12.2011.
} 
кационный класс); ежемесячная надбавка за особые условия военной службы; ежемесячная надбавка за выполнение задач, непосредственно связанных с риском для жизни и здоровья в мирное время; ежемесячная надбавка за работу со сведениями, составляющими государственную тайну.

Военнослужащему, проходящему военную службу по контракту, устанавливаются следующие дополнительные выплаты: ежемесячная надбавка за выслугу лет; ежемесячная надбавка за классную квалификацию (квалификационную категорию, квалификационный класс); ежемесячная надбавка за работу со сведениями, составляющими государственную тайну; ежемесячная надбавка за особые условия военной службы (Правила и порядок дополнительных выплат определен постановлением Правительства Российской Федерации от 21 декабря 2011 г. № 1073 «0 порядке выплаты ежемесячной надбавки за особые условия военной службы военнослужащим, проходящим военную службу по контракту» ${ }^{14}$ ); ежемесячная надбавка за выполнение задач, непосредственно связанных с риском для жизни и здоровья в мирное время (Правила выплаты определены постановлением Правительства Российской Федерации от 24 декабря 2011 г. № 1122 «0 дополнительных выплатах военнослужащим, проходящим военную службу по контракту, сотрудникам органов внутренних дел Российской Федерации за выполнение задач, связанных с риском (повышенной опасностью) для жизни и здоровья в мирное время» ${ }^{15}$ https://docviewer.yandex. ru/?url=ya-mail $\% 3 \mathrm{~A} \% 2 \mathrm{~F} \% 2 \mathrm{~F} 240000000389114325$ 7\%2F1.2\&name $=\%$ D0\%BF\%D0\%B0\%D1\%80\%D0\% B0\%D0\%B3\%D1\%80\%D0\%B0\%D1\%84\%204\%20 D0\%B3\%D0\%BB\%D0\%B0\%D0\%B2\%D0\%B0\%20 1\%20\%D0\%BE\%D1\%81\%D0\%BE\%D0\%B1\%D0 \%B5\%D0\%BD\%D0\%BD\%D0\%BE\%D1\%81\%D1 \%82\%D0\%B8\%20\%D0\%B2\%D0\%BE\%D0\%B5\% D0\%BD\%D0\%BD\%D0\%BE\%D0\%B9\%20\%D1\% 81\%D0\%BB\%D1\%83\%D0\%B6\%D0\%B1\%D1\%8B.doc\&c=5430d6fc4a06 - footnote_16); ежемесячная надбавка за особые достижения в службе (правила выплаты указанной ежемесячной надбавки определяются руководителем уполномоченным федеральным органом исполнительной власти, руководителями иных федеральных органов исполнительной власти, в которых федеральным законом предусмотрена военная служба); премия за добросовестное и эффективное исполнение должностных обязанностей, а также ежегодная материальная помощь (правила выплаты определены постановлением Правительства Российской Федерации от 5 декабря 2011 г. № 993 «0 выплате военнослужащим премии за добросовестное и эффективное исполнение должностных обязанностей и ежегодной материальной помощи» $\left.{ }^{16}\right)$; повышающие коэффициенты или надбавки к денежному довольствию, для военнослужащих, проходящих военную службу в воинских формированиях, дислоцированных за пределами территории Российской Федерации, а также военнослужащим, выполняющим задачи в условиях чрезвычайного положения, при вооруженных конфликтах, участвующим в контртеррористических операциях и обеспечивающим правопорядок и общественную безопасность на отдельных территориях Российской Федерации (правила выплаты денежного довольствия, размеры повышающих коэффициентов и надбавок к денежному довольствию на соответствующих территориях, определены постановлением Правительства Российской Федерации от 21 декабря 2011 г. № 1071 «0 выплате денежного довольствия военнослужащим, проходящим военную службу в воинских формированиях, дислоцированных за пределами территории Российской Федерации, а также военнослужащим, выполняющим задачи в условиях чрезвычайного положения, при вооруженных конфликтах» ${ }^{17}$; военнослужащим, проходящим военную службу по контракту в районах Крайнего Севера и приравненных к ним местностях, а также в других местностях с неблагоприятными климатическими или экологическими условиями, в том числе в отдаленных местностях, высокогорных районах, пустынных и безводных местностях, денежное довольствие выплачивается с учетом коэффициентов и процентных надбавок (размеры коэффициентов и процентных надбавок и порядок их применения для расчета денежного довольствия военнослужащих определены постановлением Правительства Российской Федерации от 30 декабря 2011 г. № 1237 «0 размерах коэффициентов и процентных надбавок и порядке их применения для расчета денежного довольствия военнослужащих, проходящих военную службу по контракту, и сотрудников некоторых федеральных органов исполнительной власти, проходящих

\footnotetext{
16 РГ, № 278, 09.12.2011.

17 РГ, № 297, 31.12.2011.
} 
военную службу (службу) в районах Крайнего Севера и приравненных к ним местностях, а также в других местностях с неблагоприятными климатическими или экологическими условиями, в том числе отдаленных местностях, высокогорных районах, пустынных и безводных местностях» ${ }^{18}$ ); военнослужащим, проходящим военную службу по контракту за пределами территории Российской Федерации, денежное довольствие выплачивается в иностранной валюте и в рублях в случаях, размеpax и порядке, которые определяются нормативными правовыми актами Президента Российской Федерации и (или) нормативными правовыми актами Правительства Российской Федерации.

Кроме того, Федеральный закон от 7 ноября 2011 г. № 306-Ф3 предусматривает отдельные выплаты военнослужащим: на командировочные расходы; при переезде на новое место (к месту) военной службы в другой населенный пункт (подъемное пособие и суточные); единовременное пособие при увольнении с военной службы; увеличение единовременного пособия при увольнении с военной службы на один оклад денежного содержания, военнослужащим, удостоенным в период прохождения военной службы государственных наград; пособия (единовременные выплаты, компенсация), в случае гибели (смерти) военнослужащего или гражданина, призванного на военные сборы, наступившей при исполнении им обязанностей военной службы, при увольнении военнослужащего с военной службы или отчислении с военных сборов гражданина, призванного на военные сборы, в связи с признанием его не годным к военной службе вследствие военной травмы; при установлении военнослужащему или гражданину, призванному на военные сборы, в период прохождения военной службы (военных сборов) либо после увольнения с военной службы (отчисления с военных сборов или окончания военных сборов) инвалидности вследствие военной травмы.

Федеральным законом «0 воинской обязанности и военной службе» для военнослужащих устанавливаются военная форма одежды и знаки различия (статья 39 Закона). Военная форма одежды и знаки различия утверждены Указом Президента Российской Федерации от 11 марта 2010 г. № 293 «0 военной форме одежды, знаках различия военнослужащих и ведомственных знаках отличия» ${ }^{19}$.

\footnotetext{
18 СЗ РФ, 16.01.2012, № 3, ст. 436.

19 С3 РФ, 15.03.2010, № 11, ст. 1194.
}

Как следует из Закона о статусе военнослужащих, в связи с особым характером обязанностей, возложенных на военнослужащих, им предоставляются социальные гарантии и компенсации.

Социальные гарантии и компенсации, которые предусмотрены Законом о статусе военнослужащих, федеральными конституционными законами и федеральными законами, устанавливаются: военнослужащим и членам их семей; гражданам, уволенным с военной службы в Вооруженных Силах Российской Федерации, других войсках, воинских формированиях и органах, Объединенных Вооруженных Силах государств - участников Содружества Независимых Государств, и членам их семей; гражданам, уволенным с военной службы в Вооруженных Силах Союза ССР, пограничных, внутренних и железнодорожных войсках, войсках гражданской обороны, органах и войсках государственной безопасности, других воинских формированиях Союза ССР, и членам их семей.

Для военнослужащих Законом о статусе военнослужащих устанавливается единая система правовой и социальной защиты, а также материального и иных видов обеспечения с учетом занимаемых воинских должностей, присвоенных воинских званий, общей продолжительности военной службы, в том числе и в льготном исчислении, выполняемых задач, условий и порядка прохождения ими военной службы.

Социальная защита военнослужащих, граждан, уволенных с военной службы, и членов их семей является функцией государства и предусматривает: реализацию их прав, социальных гарантий и компенсаций органами государственной власти, органами военного управления и органами местного самоуправления; совершенствование механизмов и институтов социальной защиты указанных лиц; охрану их жизни и здоровья, а также иные меры, направленные на создание условий жизни и деятельности, соответствующих характеру военной службы и ее роли в обществе.

Реализация мер правовой и социальной защиты военнослужащих, граждан, уволенных с военной службы, и членов их семей возлагается на органы государственной власти, органы местного самоуправления, федеральные суды общей юрисдикции, правоохранительные органы в пределах их полномочий, а также является обязанностью командиров (начальников).

Государство гарантирует военнослужащим, проходящим военную службу по контракту увеличение количества социальных гарантий и размера 
компенсаций в соответствии с полученной квалификацией и со сроком военной службы.

Примером отдельных социальных гарантий являются: возможность получения дополнительного профессионального образования с учетом интересов военной службы и их собственного выбора; супругам военнослужащих, проходящих военную службу по контракту, в общий трудовой стаж, необходимый для установления пенсии, засчитывается весь период проживания с супругами до 1992 года вне зависимости от мест дислокации воинских частей, с 1992 года - в местностях, где они не могли трудиться по специальности в связи с отсутствием возможности трудоустройства и были признаны в установленном порядке безработными; супруги военнослужащих при прочих равных условиях имеют преимущественное право на поступление на работу в государственные организации, воинские части и на оставление на работе в государственных организациях, воинских частях при сокращении численности или штата работников, а также на первоочередное направление на прохождение профессионального обучения или для получения дополнительного профессионального образования по очной форме обучения с выплатой в период обучения средней заработной платы; военнослужащие, проходящие военную службу по контракту, в период прохождения ими военной службы имеют право на улучшение жилищных условий с учетом норм, очередности и социальных гарантий, установленных федеральными законами и иными нормативными правовыми актами Российской Федерации; военнослужащие и граждане, призванные на военные сборы, имеют право на бесплатное получение медицинской помощи, члены семей военнослужащих имеют право на медицинскую помощь в медицинских организациях государственной или муниципальной систем здравоохранения и подлежат обязательному медицинскому страхованию на общих основаниях с другими гражданами; военнослужащие и граждане, уволенные с военной службы по достижении ими предельного возраста пребывания на военной службе, состоянию здоровья или в связи с организационноштатными мероприятиями, - участники войны имеют преимущественное право на получение медицинской помощи и санаторно-курортное лечение; зачет времени военной службы в стаж государственной службы государственного служащего в случае поступления на работу в органы государственной власти; гражданам, уволенным с военной службы по достижении ими предельного возраста пребывания на военной службе, состоянию здоровья или в связи с организационно-штатными мероприятиями, имеющим общую продолжительность военной службы 20 лет и более, до 1 января 2015 года выплачивается денежная компенсация в размере фактически уплаченных ими земельного налога и налога на имущество физических лиц; военнослужащий, проходящий военную службу по контракту и не достигший предельного возраста пребывания на военной службе, не может быть уволен с военной службы без его согласия до приобретения им права на пенсию за выслугу лет, за исключением случаев досрочного увольнения по основаниям, установленным Федеральным законом.

Военнослужащие, общая продолжительность военной службы которых составляет 10 лет и более, нуждающиеся в улучшении жилищных условий по нормам, установленным федеральными законами и иными нормативными правовыми актами Российской Федерации, без их согласия не могут быть уволены с военной службы по достижении ими предельного возраста пребывания на военной службе, состоянию здоровья или в связи с организационно-штатными мероприятиями без предоставления им жилых помещений или жилищной субсидии.

С учетом изложенного, можно сделать вывод о том, что большинство из перечисленных отличительных признаков военной службы имеют особый характер.

Основные отличия военной службы от гражданской государственной службы заключается в предназначении этих видов государственной службы, в выполняемых ими функциях и задачах.

Особенность военной службы заключается в исполнении военнослужащими специфических функций, в целях обеспечения обороны и безопасности Российской Федерации, специальными методами с применением или возможностью применения средств вооруженной борьбы (вооружения и военной техники) с противником, закрепленных федеральным законодательством.

Специфика военной службы проявляется в том, что с учетом детальной регламентации правовыми актами военно-служебных отношений, не всегда представляется возможным, установить (определить) порядок действий военнослужащего в той или иной ситуации, в частности во время ведения боевых действий, что также подчеркивает особый статус военной службы. 


\section{Библиография:}

1. Кудашкин А.В. Статья: К вопросу о сущности военной службы и ее месте в системе государственной службы. «Право в Вооруженных Силах», № 8, 2003.

2. Корякин В.М., Кудашкин А.В., Фатеев К.В. Военно-административное право (военная администрация). Учебник. М.: За права военнослужащих, 2008. Вып. 90.496 с.

3. С РФ, 03.06.1996, № 23, ст. 2750.

4. $Р$ Р, № $124,04.06 .2014$.

5. СЗ РФ, № 22, 01.06.1998, ст. 2331.

6. $\quad$ СЗ РФ, № 47 (1 ч.), 19.11.2007, ст. 5749.

7. Колибаба Г.Н. Правовые основы советской военной службы: Дис. канд. юрид. наук. М., 1955. С. 54.

8. СЗ РФ, 30.03.1998, № 13, ст. 1475.

9. СЗ РФ, 20.09.1999, № 38, ст. 4534.

10. Попов Л.Л., Мигачев Ю.И., Тихомиров С.В. Административное право России: учебник.-2-е изд., перераб. и доп. (отв. ред. Попов Л.Л.).-М.: "Проспект", 2010.

11. СЗ РФ, 07.11.2011, № 45, ст. 6336.

12. РГ, № 278, 09.12.2011.

13. РГ, № 293, 28.12.2011.

14. РГ, № 296, 30.12.2011.

15. РГ, № 297, 31.12.2011.

16. СЗ РФ, 16.01.2012, № 3, ст. 436.

17. СЗ РФ, 15.03.2010, № 11, ст. 1194.

\section{References (transliterated):}

1. Kudashkin A.V. Stat'ya: K voprosu o sushchnosti voennoi sluzhby i ee meste v sisteme gosudarstvennoi sluzhby. «Pravo v Vooruzhennykh Silakh», № 8, 2003.

2. Koryakin V.M., Kudashkin A.V., Fateev K.V. Voenno-administrativnoe pravo (voennaya administratsiya). Uchebnik. M.: Za prava voennosluzhashchikh, 2008. Vyp. 90. $496 \mathrm{s.}$

3. SZ RF, 03.06.1996, № 23, st. 2750.

4. RG, № 124, 04.06.2014.

5. SZ RF, № 22, 01.06.1998, st. 2331.

6. $\quad$ SZ RF, № 47 (1 ch.), 19.11.2007, st. 5749.

7. Kolibaba G.N. Pravovye osnovy sovetskoi voennoi sluzhby: Dis. kand. yurid. nauk. M., 1955. S. 54.

8. SZ RF, 30.03.1998, № 13, st. 1475.

9. SZ RF, 20.09.1999, № 38, st. 4534.

10. Popov L.L., Migachev Yu.I., Tikhomirov S.V. Administrativnoe pravo Rossii: uchebnik.-2-e izd., pererab. i dop. (otv. red. Popov L.L.).-M.: "Prospekt", 2010.

11. SZ RF, 07.11.2011, № 45, st. 6336.

12. RG, № 278, 09.12.2011.

13. RG, № 293, 28.12.2011.

14. $\mathrm{RG}$, № $296,30.12 .2011$.

15. RG, № 297, 31.12.2011.

16. SZ RF, 16.01.2012, № 3, st. 436.

17. SZ RF, 15.03.2010, № 11, st. 1194. 